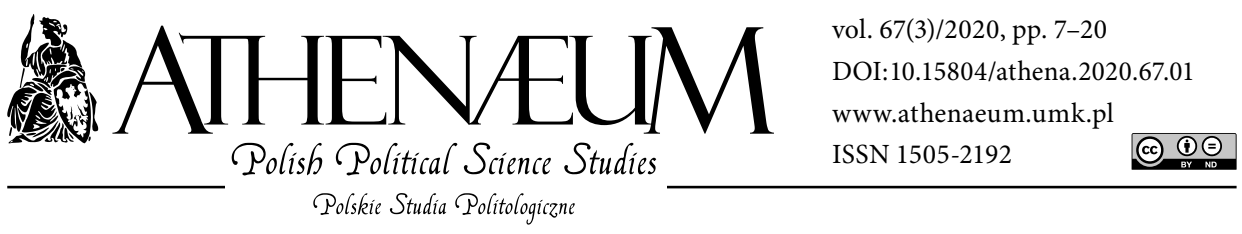

\title{
GREAT BRITAIN AFTER BREXIT - IS BRETURN POSSIBLE?
}

\author{
WIELKA BRYTANIA PO BREXICIE - \\ CZY MOŻLIWY JEST BRETURN?
}

\author{
Łukasz Danel*
}

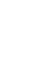

\section{- ABSTRACT}

The article is devoted to the problem of further steps that Great Britain could take to break the stalemate in which it found itself after June 2016 when the British decided to leave the European Union. Despite making this decision, it turned out that its implementation was unexpectedly difficult, which in turn caused a political crisis in Great Britain that has not been seen in this country for a long time.

The aim of the article is to try to find answers to two research questions. First of all, could the Brexit process - both from a legal and political point of view - have been stopped and reversed, for example, by holding a second referendum? Secondly, whether, since Brexit has become a fact, we can expect a quick return of Great Britain to the European Union ("Breturn").

Using the method of institutional and legal analysis and the content analysis method, the Author tries to prove the thesis that the idea of a second referendum seemed unlikely, and hence - Brexit was rather inevitable. As for
\end{abstract}

Artykuł poświęcony jest problemowi dalszych kroków, które Wielka Brytania mogła podjąć, by wybrnąć z impasu, w którym znalazła się po tym, gdy Brytyjczycy w czerwcu 2016 roku podjęli decyzję o wyjściu z Unii Europejskiej. Mimo podjęcia tej decyzji okazało się, że wprowadzenie jej w życie było nadspodziewanie trudne, co kolei wywołało w Wielkiej Brytanii kryzys polityczny, jakiego w kraju tym nie było od bardzo dawna.

Celem artykułu jest próba znalezienia odpowiedzi na dwa pytania badawcze. Po pierwsze - czy proces Brexitu, zarówno z prawnego, jak i politycznego punktu widzenia, mógł zostać zatrzymany i odwrócony, przykładowo - $\mathrm{w}$ drodze drugiego referendum. Po drugie zaś, czy w związku z tym, że Brexit stał się faktem - możemy się spodziewać szybkiego powrotu Wielkiej Brytanii do Unii Europejskiej („Breturn”).

Wykorzystując metodę analizy instytucjonalno-prawnej oraz metodę analizy treści, Autor stara się wykazać, że idea drugiego referendum wydawała się mało prawdopodobna, a co za tym

\footnotetext{
* Cracow University of Economics, Department of Political Studies.
} 
"Breturn" - this scenario also looks unrealistic, as it would involve various legal and political obstacles as well as practical inconveniences for Great Britain.

Keywords: Brexit; Breturn; Great Britain; European Union; referendum idzie - Brexit był raczej nieunikniony. Jeśli zaś chodzi o „Breturn” - scenariusz taki również wygląda na mało realistyczny, gdyż jego ziszczenie wiązałoby się z różnego rodzaju przeszkodami natury prawnej i politycznej, jak również z praktycznymi niedogodnościami dla Wielkiej Brytanii.

Słowa kluczowe: Brexit; Breturn; Wielka Brytania; Unia Europejska; referendum

\section{INTRODUCTORY REMARKS}

When in June 2016, in a nationwide referendum, the British decided to leave the European Union, it could be predicted that the process of leaving the Union - for many reasons - will not be easy. It is enough to mention that this is an absolutely unprecedented situation, because so far the European Union has only accepted new members. And even if Article 50 of the Treaty on the European Union introduced for the first time a procedure for a member state to withdraw voluntarily from the EU, this has never been put into practice before.

Nevertheless, probably no one was able to predict that Brexit would be so complicated that even postponing its deadline two times made it so difficult to bring the intended results. This was undoubtedly a problem for both parties. From the Brussels perspective, this impasse showed that the European Union could not bring the whole process to an end, which only intensified the already noticeable divisions within it, at the same time strengthening the Eurosceptic political parties and movements in EU member states. In London, in turn, we were observing a growing political and constitutional crisis, manifesting itself in the change of the prime minister, a paralysis of the functioning of the British parliament, as well as a radical conflict between the government and the opposition. The confusion of British citizens was rarely mentioned, although it seemed that they were increasingly losing faith in their institutions, as well as trust in political elites and the entire political system. British democracy, which had long been a role model in Europe and beyond, gave the impression of being in a serious crisis, which until recently seemed almost unimaginable.

In parallel to the debate about the date and conditions of Brexit, as well as very advanced preparations for this process, there was also a discussion in Great Britain on the annulment of the decision to leave the European Union, in other 
words - the revocation of Article 50 invoked on 29 March 2017. And even if it was legally possible, it was hard to imagine that British politicians would have taken such a step without prior approval from the citizens expressed in a second referendum. The second referendum initiative appeared soon after the 2016 referendum results had been announced. There were in fact a couple of different options that could have been put to such a referendum. And though it was usually said, that a further Brexit referendum could have particularly been aimed at approving the withdrawal agreement negotiated by the British government in Brussels, one of its viable options was also a direct question whether the United Kingdom should have remained a member state of the EU. That could have, if the majority of voters answered 'yes', led to the cancellation of Brexit. On the other hand, assuming that Great Britain - regardless of the content of the agreement, or even whether it was concluded at all - would leave the European Union anyway, the "Breturn" initiative appeared, boiling down to the fact that after some time Great Britain could simply return to the EU.

The aim of the article is to try to find answers to two research questions based on the problems outlined above. First of all, could the Brexit process have been stopped or even reversed from a legal and political point of view? Secondly, assuming that Great Britain would eventually cease to be the member state of the European Union, can we expect its return to this organization in the near future, and if so - under what conditions and on what terms?

The author will try to prove the thesis that the idea of a second referendum was highly unlikely, because it would have led to even greater chaos than the one experienced by the British in their country. Similarly, the rapid return of Great Britain to the European Union also seems unlikely - it is not so much legal issues or treaty restrictions as practical and political factors that can stand in the way. To address the research problem outlined above, both the institutional and legal analysis method and content analysis method are used.

\section{THE POTENTIAL REVOCATION OF ARTICLE 50}

The question whether Brexit could have been stopped is actually a question whether the invocation of Article 50 of the Treaty on the European Union is a reversible or irreversible decision. This article - enacted by the Treaty of Lisbon on 1 December 2009 - recognises the right of a member state to withdraw from the European Union as well as depicts the procedure according to which such 
a withdrawal may be carried out. The Treaty makes no mention of what happens when a member state wants to revoke an earlier decision. Therefore, in order to answer the question whether the notification of the decision to leave the EU after such notification had been made by a member state - can still be annulled, we must consider this situation both in legal and political terms.

From a legal point of view the answer to this question seems pretty obvious - of course it still can be annulled. This is primarily in line with the Vienna Convention on the Law of Treaties - a special agreement which entered into force in 1980 and regulates treaties between states. The Convention allows a state to revoke its decision to withdraw from any international treaty which means that this provision could also have been applied to Brexit. In December 2018, the European Court of Justice confirmed this interpretation when it ruled that the United Kingdom could unilaterally, by simply writing a letter to the European Council, revoke Article 50 of the Treaty on the European Union. And it could have been done without the unanimous consent of the remaining 27 member states represented in the European Council (Judgment in Case C-621/18, 2018). Moreover, according to the ruling, the decision to revoke Article 50 is expected to be "unequivocal and unconditional" what should be understood in such a way that a given state must clearly indicate that its will is to retain its status as a member state of the European Union. It also suggests that the UK could not have revoked Article 50 in order to extend the transition period for more than two years buying this way more time to prepare itself for the whole process.

Regarding time limits, one more point of the court decision should be emphasized. The European Court of Justice ruled that the possibility to revoke Article 50 exists for as long as a withdrawal agreement - which sets the terms of departure - concluded between the EU and that member state has not entered into force. If no such agreement has been concluded, revocation may take place for as long as the two-year period from the date of the notification of the intention to withdraw from the EU has not expired. In case of any extension of that two-year period given by the remaining member states, the potential revocation of Article 50 may also take place during this extended period (Judgment in Case C-621/18, 2018).

As it has been rightly noted by some lawyers, the ruling of the European Court of Justice was not surprising at all. If - according to the Treaty on the European Union - it is each member state's sovereign decision to leave the EU, then exactly the same sovereign decision should be to revoke that intention. In other words, the final decision on further membership in the European Union belonged only to the United Kingdom. If it finally decided to revoke Article 50 
and remain in the EU, it would have basically happened automatically and the EU could not have imposed any additional conditions in this regard (Petrucci, 2018). What is more, the European Court of Justice ruled that such a revocation confirms the EU membership of the member state concerned under terms that are unchanged, which means that the United Kingdom would then have remained a member state of the European Union on exactly the same terms as it had before (so including keeping, e.g., its opt-outs or the famous budget rebate). If it happened, that would have simply brought the withdrawal procedure to an end as if nothing had happened.

So from a legal point of view, Great Britain's decision to leave the European Union could have been reversed, and therefore Brexit could have been stopped. For this to have happened, first of all, political will and, secondly, formal notification of this intention were needed. The legal perspective is, however, only one side of the coin. The other one is definitely more complicated and it is related to political conditionings of the potential revocation of Article 50. According to the European Court of Justice, the revocation must be decided following a democratic process in accordance with national constitutional requirements. Given the fact that the British constitutional system is relatively complicated, this opens up room for new discussion.

Naturally, the European Court of Justice has in no way suggested which institution of the British political system should have made a potential decision to revoke Article 50. Whether it was to be the parliament or the government would have had to be determined by the British themselves. Theoretically the government could have done it itself (so without consulting parliament) by using Royal Prerogative. However, the use of prerogative was already challenged during the course of the Brexit process. It happened at the beginning of 2017 when the government intended to invoke Article 50. The Supreme Court of the United Kingdom ruled then that triggering the EU exit process required the consent of the parliament ( $\mathrm{R}$ [on the application of Miller and another], 2016). In other words a special act of parliament was needed for this decision to be effective. It can therefore be assumed that in the case of the potential revocation of Article 50 the procedure would have been the same - such a decision probably could not have been made by the government without the prior consent of the parliament. If, in turn, the parliament wanted to force the government to revoke Article 50 , that could have happened if majority of MPs were able to take control of parliamentary business and instruct the prime minister to do so. Such a situation had also already taken place in the Brexit process (Schraer, 2019). 
One should also remember about potential political and social implications of such a decision. The revocation of Article 50 could surely have been interpreted as the violation of the will of the British people expressed in the referendum. This in turn would have carried the risk of social protests and maybe even revolt. On the other hand, it is also worth emphasizing that a petition submitted to the UK Parliament petitions website calling on the government to revoke Article 50 of the Treaty on European Union, and remain a member state of the European Union (so called "Revoke Article 50 and remain in the EU petition") received more than 6 million signatures, which is a record number in the history of the British parliament (Petitions UK Government and Parliament, 2019).

\section{THE IDEA OF A SECOND REFERENDUM}

The potential revocation of Article 50 - no matter who would ultimately be entitled to make such a decision - could have been preceded by another Brexit referendum. To the question whether another referendum on Brexit was still possible there is only one correct answer - of course it was. According to the principle of parliamentary sovereignty, that would have only required special legislation passed by the British parliament, just like in case of the Brexit referendum that was held on 23 June 2016.

In fact, the first calls for a further referendum on Brexit (called by some a 'People's Vote') appeared shortly after the original vote. Initially, these calls resulted from the expectation that British citizens would be able to have the final say on the withdrawal agreement, that is, the deal negotiated between the British government and the European Union - that they would be able to either accept or reject it. Such expectations were expressed by both politicians and representatives of different pressure groups and well as other socio-political movements or expert groups. On the contrary, the opponents of the referendum argued that another vote would lead to even greater social divisions and social unrest and would undermine the idea of democracy.

The first e-petition calling for a second referendum received more than 4 million signatures. It is worth explaining that the petition was started yet before the first referendum by leave activists who were expecting another result (at that time polls suggested 'remain' would win). The petition opted for the second vote in case the turnout did not exceed $75 \%$ and the winning option did not get more than $60 \%$ of a vote (Petitions UK Government and Parliament, 2016). However, 
after the debate in parliament, the petition was rejected. The government argued that it was a "once in a generation vote" (Slawson, 2016). What is more, at that time opinion polls indicated that only around $30 \%$ of the public supported the idea of a second referendum.

In 2017, in the electoral campaign before the United Kingdom general election, the Liberal Democrats (though earlier fairly divided on this issue), the Green Party as well as several minor political parties publicly advocated a second referendum. Individual Tory and Labour politicians expressed similar opinions, though this was not the official agenda of any of these parties. In April 2018, a pressure group "People's Vote" was launched by pro-European activists, 'remain' supporters as well as local politicians, individual MPs, public figures and some celebrities. It called for a public vote on the final text of the withdrawal agreement negotiated between the United Kingdom and the European Union (People's Vote, https://www.peoples-vote.uk). At that time some of the polls showed that in case of a second referendum around $60 \%$ of voters, if they had the chance to do so, would vote in favour of staying in the European Union. That would mean that, compared to the first referendum, more than 2,5 million Britons changed their minds and withdrew their support for Brexit. That is why "People's Vote" organized several multi-million demonstrations and held lots of campaign rallies - primarily in London but also throughout the UK - during which people demanded a second referendum. They were accusing the leaders of the 'leave' camp of misinformation and emphasized the need for a referendum using the argument that the terms of Brexit were unknown to the public at the time of the original referendum. When they are finally known, the British should be able to make a final decision regarding their country. "People's Vote" proposal was to allow a choice between 'accept the deal' (and thus - leave) and 'remain'. Such subject of the referendum was also accepted by almost all of the third parties.

Within the Conservative Party two groups emerged representing two different, clashing positions. One of them were supporters of hard bargaining with Brussels, who in the event of failure of these talks were ready to accept the socalled "no-deal Brexit". The other group, led by the Prime Minister Theresa May, showed more conciliatory attitude towards Brussels and opted for a compromise with the EU that would be acceptable to most of the MPs. Neither of these two groups officially supported the second referendum because - according to May's famous expression - "Brexit means Brexit".

For the Labour Party, in turn, the idea of the second referendum, just like the whole of Brexit, has become, over time, an extremely difficult political problem. 
In the fight for party leadership in 2016, Jeremy Corbyn rejected the idea of a second referendum whereas his opponent - Owen Smith - pledged to support it. One of the turning points in this process was the declaration issued in September 2018 by Frances O'Grady, the leader of Labour's close ally - Trades Union Congress (TUC). She said that she would demand "a popular vote" unless the government struck "the deal that working people need" with the EU (BBC News, 2018). Soon after, at the party conference, delegates voted overwhelmingly for a motion that calls for a second referendum in the event that parliament fails to approve an eventual deal. This was a significant change in the position of the party leadership though still without a clear call for a second referendum. The situation changed even more after seven MPs decided to leave the Labour Party and establish "The Independent Group" (TIG) ${ }^{1}$. They were soon joined by one more Labour MP as well as three Tory MPs. What brought them all together was dissatisfaction with how their party leaders were dealing with Brexit and their support for a second referendum on EU membership (The Independent Group for Change, n.d.). This forced the Labour leadership to take a risky move and officially back a second referendum (with 'remain' as an option) if the party should fail to get its own version of a Brexit deal passed (Elgot, 2019). In September 2019, the Labour Party went a step further announcing that the next Labour manifesto would include a commitment to hold a referendum in which people will be able to decide whether they want Great Britain to leave the EU in accordance with the negotiated agreement, or whether they want Great Britain to remain the EU member state.

It is also worth mentioning that the proposal for a second referendum was three times rejected by the British parliament in March and April 2019. On 14 March, MPs rejected an amendment (tabled by one of the members of TIG) which called for a second Brexit referendum. The motion was rejected by 334 votes to 85 with vast majority of the Labour MPs abstaining (Votes in Parliament, https://votes.parliament.uk). On 27 March and 1 April, two rounds of so called 'indicative votes' took place. Each time they included a proposal for a second referendum but both of them failed to get enough support in the House of Commons (268-295 and 280-292).

The public opinion on the second referendum has also shifted since 2016. According to different polls, the number of referendum supporters equalled the one of its opponents. The results of the polls differ slightly because they depend

\footnotetext{
${ }^{1}$ Its current name is "The Independent Group for Change”.
} 
on the content of the question about the various referendum options given to the respondents, but regardless of this the British citizens seem to be much more willing to have the final say on Brexit in 2019 than they were in 2016-20182.

As for the subject of the referendum, and thus the possible referendum question, many different ideas and suggestions have emerged. The most popular of them was a potential choice between remaining in the European Union and approving the negotiated withdrawal agreement, though other options were also taken into consideration. The authors of a report prepared in October 2018 by the Constitution Unit of the University College London emphasized that any further referendum must first and foremost be very carefully designed to maximize public legitimacy for the final decision, no matter what it would be. This was particularly important at a time when the political divide in the United Kingdom was so deep that politics was evoking very negative and often even confrontational emotions among citizens (Sargeant, Renwick, \& Russell, 2018, pp. 3-4). The report identified three viable options that could have been put to a second referendum: accepting the deal negotiated by the government, remaining in the EU, or leaving without a deal. The option of negotiating a different deal was excluded as unsuitable for such a referendum. Regarding different question formats that could have been presented to voters, in principle two scenarios seemed most likely - either a choice between 'deal' and 'remain', or a three-option referendum: the two above-mentioned and additionally'no deal' (Sargeant et al., 2018, p. 58).

Holding a second referendum on Brexit, which is also worth remembering, would have carried some risk. No matter which option would ultimately have been chosen and what question would ultimately have been put before the voters, this would have caused controversy among the British. To make sure that the result of such a referendum would have been accepted by all sides of political discourse, the whole process would have had to be as legitimate as possible. That included the principles of running a referendum campaign, proper conduct of voting as well as asking a clear question with unambiguous and precise answer options (Sargeant et al., 2018, p. 8).

${ }^{2}$ For detailed results of different polls regarding the second referendum and Brexit, see e.g.: https://whatukthinks.org/eu/. 


\section{BRETURN - FICTION OR A REAL SCENARIO?}

Taking into consideration everything that has happened in the British politics since the 2016 referendum, it could be assumed that the chances of calling a second referendum were, for many reasons, rather low. All signs pointed to great determination of the British government, and above all the Prime Minister Boris Johnson himself, to finalize Brexit as soon as possible, even if it meant leaving the European Union without any deal. That is why Brexit seemed inevitable. No politician, especially the leader of one of the two main parties, would have been brave enough to play va banque and, for example, revoke Article 50 or strive for another referendum at all costs. Authorization to do this had not been granted to the government even once - neither by the parliament (above-mentioned 'indicative votes'), nor by the British society, invariably very divided on Brexit. Therefore, mainly for this reason, making such decisions would have been definitely too risky and maybe even politically suicidal.

In general, there was no favourable climate in Great Britain to take such action. The political configuration in the British parliament meant the continuation of Theresa May's government policy, and perhaps even a more demanding attitude and a more radical approach to talks with Brussels. On the other hand, it was also hard to expect another snap election, as for both the Conservative Party and the Labour Party, its results could have been devastating. Therefore, Prime Minister Johnson did everything to deliver the will of the British people, i.e., bring Brexit to an end.

However, quite unexpectedly, another snap election was called, and after the landslide victory of the Conservative Party, the entire Brexit process significantly accelerated. The United Kingdom left the European Union on 31 January 2020. A transition period during which the UK must comply with all EU rules and laws is expected to last until 31 December 2020. A question can therefore now be asked whether we should expect UK's return to the European Union after some time. In this context, it is also worth mentioning the declarations of some European politicians like Jean-Claude Juncker or Donald Tusk who had repeatedly, yet before Brexit happened, expressed the hope that Great Britain would reconsider its decision because its withdrawal from the EU would lead to mutual losses and would be economically devastating for both sides.

The idea of so called "Breturn", as it was dubbed on some social media, could come true under several conditions. First of all, the post-Brexit reality would have to be definitely more difficult for Great Britain than even the most pessimistic 
forecasts and predictions made by some experts and economists. It is worth remembering that, according to the architects of Brexit, Great Britain decided to to leave the European Union not without a reason. In their vision Great Britain is supposed to be stronger outside the EU than it was as its member state. However, if it is not going to happen, there is a huge chance that after some time the British could be willing to return to the European Union.

Of course, in the current situation, this can only be seen as one of the potential scenarios for the future. Many factors will determine whether this scenario becomes reality. Much will depend on what kind of losses - both the economic and political ones - Brexit will bring for Great Britain. This, in turn, is very difficult to predict, especially when it comes to economic repercussions. It is no secret that this area is the most sensitive for the British. In fact, since the referendum, there have been serious warnings expressed by different economists that the Brexit's side effects may be very far-reaching and devastating for both the British and even the global economy. The most serious warnings are about the British currency, the London stock market and the banking sector - some banks have already started to look for new offices on the European continent, e.g., in Paris or in Frankfurt. What is more, due to the high uncertainty about the future, a lot of companies have postponed making investments in the United Kingdom (Lynn, 2016). And this was just the beginning.

From the legal point of view - according to the Article 49 of the Treaty on the European Union - if one day Great Britain decides to rejoin the European Union, having formally left, it would be able to apply for re-admission to the Union practically at any time. It is very likely that such a decision would have to be taken by the British in a referendum. However, regardless of the procedure, this would involve the need to negotiate the terms of such new membership, like in the case of any other state that wants to join the European Union.

Even if one day the British are willing to re-join the EU, the Union will probably not be as generous as before and will not agree to such opt-outs that have so far allowed Great Britain to keep its currency or to stay outside the Schengen zone. Let alone the famous British budget rebate negotiated by the Margaret Thatcher's government. Such issues and complexities, as well as many additional ones, would be on the table once again. From this point of view, it was probably better for the British not to leave the European Union at all than to leave and after some time try to come back to it. 
On one side, it could have been predicted that the process of leaving the European Union, after being part of it for more than 40 years (originally within the European Communities, since 1993 within the EU) would not be smooth and easy for Great Britain. Obviously, it should be taken into account that the European Union, as a political entity, may be characterized as a supranational organization, which means that the integration within it is very advanced. In certain areas the EU has exclusive competence to make European law which, according to one of the basic principles of the European integration, is superior to the national law of EU member states. EU's institutions have very broad powers that go far beyond the classical scope of competence known from other international organizations.

On the other side, however, it could not have been predicted that Brexit would bring so much complications. Over the three and a half years since the 2016 referendum, it turned out that neither the British government nor the British parliament could bring this process to an end. During this period of time various politicians were responsible for negotiations with the European Union on behalf of the government and - as a result of the political deadlock - even a change of prime minister took place. Let alone a snap election or the UK's Supreme Court ruling that the suspension of parliament was unlawful. The British parliament, which shortly after the referendum reserved itself the right to finally accept the withdrawal agreement, rejected three different versions of such an agreement, which forced the government to ask the EU for two extensions - the second of which until 31 October 2019. The parliament itself was not able to come up with any alternative scenario. In three memorable series of so called 'indicative votes', none of the options obtained the required majority in the House of Commons. What is more, the famous Benn Act (European Union [Withdrawal], 2019), passed by the parliament in September 2019 required the prime minister to seek another extension if (by 19 October) no new deal was reached. Once again it strengthened the parliament which had to give its consent not only to a withdrawal agreement but also to a potential no-deal Brexit.

All these complications led to a situation in which considerations on whether Great Britain should revoke Article 50, and therefore remain in the EU, became more and more serious and took on new meaning. More and more discussions also began over the possible second referendum, which could have also resulted in Great Britain remaining a member state of the European Union. All these 
discussions ended with the UK snap election held on 12 December 2019. After the victory of the Conservative Party, the final decision to leave the European Union was only a matter of time. This in turn has led to the growing popularity of the idea of "Breturn" which would make it possible to treat Brexit only as a transitory phenomenon.

The aim of the article was to prove a thesis that the idea of a second referendum was highly unlikely. One might say that so many strange and difficult to predict things had happened around Brexit, that nothing was excluded. However, a second referendum, even though expected by a significant part of the public opinion, would have probably been a step too far and led to even greater political chaos. On the other hand, it was also hard not to take into account the arguments that the British should be able to have the final say on Brexit - once the terms of the withdrawal agreement were known or once it was known whether such an agreement would be signed at all. There were no legal obstacles for such a referendum to take place, just as there were no legal obstacles for the British government to decide by itself to revoke Article 50. Nevertheless, the legal perspective would not have been sufficient to justify such a decision. In this particular case, political circumstances were far more important than the legal ones. And these were extremely complex and risky since Brexit - with a withdrawal agreement or without it - seemed to be inevitable.

As for the possible "Breturn", its most important determinant is time, i.e., how Great Britain will be doing outside the EU and whether the pessimistic scenarios written by some politicians, experts and economists will become reality. If so, everything is possible, though there are lots of procedural and political factors that could stand in the way.

Once it seemed that accession to the European Union has such far-reaching consequences that no country will decide to voluntarily leave this organization. It turned out that is not necessarily true anymore. That is why also a return scenario should not definitely be ruled out.

\section{REFERENCES:}

BBC News (2018, September 9). Brexit: TUC Issues New EU Referendum Warning to May. Retrieved from: https://www.bbc.com/news/uk-politics- 45464115.

Elgot, J. (2019, February 25). Jeremy Corbyn: We'll Back a Second Referendum to Stop

Tory No-deal Brexit. The Guardian. Retrieved from: https://www.theguardian.com/ politics/2019/feb/25/labour-to-back-moves-for-second-brexit-referendum. 
European Union (Withdrawal) (No. 2) Act (2019).

Judgment in Case C-621/18 (2018). Wightman and Others v Secretary of State for Exiting the European Union. The Court of Justice of the European Union, Luxembourg. Retrieved from: http://curia.europa.eu/juris/document/document.jsf?text $=\&$ docid $=208636 \&$ pageIndex $=0 \&$ doclang $=$ en \&mode $=$ req \&dir $=\& o c c=$ first $\& p a r t$ $=1 \&$ cid $=1087903$.

Lynn, M. (2016, June 28). Opinion: After Brexit, Get Ready for a Breturn as Britain Reverses Course. Market Watch. Retrieved from: https://www.marketwatch.com/ story/after-brexit-get-ready-for-a-breturn-as-britain-reverses-course-2016-06-28.

People's Vote. Retrieved from: https://www.peoples-vote.uk/.

Petitions UK Government and Parliament (2016). EU Referendum Rules Triggering a $2^{\text {nd }} E U$ Referendum. Retrieved from: https://petition.parliament.uk/archived/ petitions/131215.

Petitions UK Government and Parliament (2019). Revoke Article 50 and Remain in the EU. Retrieved from: https://petition.parliament.uk/petitions/241584?utm_ source $=$ HeyMP.

Petrucci, C. (2018, December 10). Article 50 Can Be Revoked: Here's What It Means for Brexit. The Conversation. Retrieved from: https://theconversation.com/article50-can-be-revoked-heres-what-it-means-for-brexit-108522.

$\mathrm{R}$ (on the application of Miller and another) (Respondents) v Secretary of State for Exiting the European Union (Appellant) (2016). The Supreme Court, UKSC 2016/0196. Retrieved from: https://www.supremecourt.uk/cases/docs/uksc-20160196-judgment.pdf.

Sargeant, J., Renwick, A., \& Russell, M. (2018). The Mechanics of a Further Referendum on Brexit. The Constitution Unit. University College London.

Schraer, R. (2019, October 18). Article 50: Can the UK Cancel Brexit? BBC News. Retrieved from: https://www.bbc.com/news/uk-politics-47668466.

Slawson, N. (2016, July 10). Brexit: No Second EU Referendum despite e-Petition, Says Government. The Guardian. Retrieved from: https:/www.theguardian.com/ politics/2016/jul/09/government-dashes-hopes-of-second-eu-referendum-in-epetition-response.

The Independent Group for Change (n.d.). Retrieved from: https://voteforchange.uk/. Votes in Parliament. Retrieved from: https://votes.parliament.uk/Votes/Commons/ Division/629. 